\title{
Pola Komunikasi Pimpinan Cabang Ikatan Pelajar Nahdlatul Ulama' (IPNU) Kabupaten Ponorogo Dalam Menanggulangi Radikalisme
}

\author{
Ahmad Faizin Ngajibullah \\ Fakultas Dakwah, Institut Agama Islam Sunan Giri (INSURI) Ponorogo, Ponorogo, Indonesia \\ Faiznoto3@gmail.com \\ M. Mufid Syakhlani \\ Fakultas Dakwah, Institut Agama Islam Sunan Giri (INSURI) Ponorogo, Ponorogo, Indonesia \\ Mengajinusantara25@gmail.com
}

\begin{abstract}
Abstrak
Penelitian ini bertujuan untuk Mengetahui Cara Pimpinan Cabang Ikatan Pelajar Nahdlatul Ulama' Kabupaten Ponorogo Dalam Menangkal Faham Radikalisme dan Mengetahui Komunikasi yang Diterapkan Pimpinan Cabang Ikatan Pelajar Nahdlatul Ulama' Kabupaten Ponorogo Dalam Menanggulangi Faham Radikalisme. Penelitian ini mengunakan pendekatan kualitatif yang memiliki karakteristik sumber data langsung, deskripsinya bersifat penyampaian pola komunikasi pimpinan PC IPNU Ponorogo Hasil penelitian ini adalah cara pimpinan PC IPNU Ponorgo dalam menangkal faham radikalisme yaitu dengan memberikan pengetahuan akan bahayanya faham radikalisme khususnya bagi para pelajar lewat berbagai macam media yang ada dan kegiatan yang ada di PC IPNU Ponorogo, selain itu pimpinan PC IPNU Ponorogo juga memberi contoh kepada kader sikap toleransi dan menghargai tradisi yang sudah ada di kabupaten Ponorogo. Dan Pola komunikasi yang digunakan adalah komunikasi primer, skunder, literal, dan sikular. Dan ada juga komunikasi yang dilakukan oleh pimpinan PC IPNU Ponorogo yaitu dengan komunikasi massa dan komunikasi kelompok, komunikasi ini dilakukan dengan cara memberikan informasi faham radikalisme lewat seminar, kajian dan informasi yang di dapat oleh pimpinan PC IPNU Ponorogo di broadcast kepada kader IPNU lewat group Whatsapp
\end{abstract}

Kata kunci: Komunikasi, Pimpinan, IPNU, Radikalisme

\begin{abstract}
This study aims to find out how the leaders of the Nahdlatul Ulama 'Student Association branch in Ponorogo Regency to counteract radicalism and to know the communication applied by the leaders of the Nahdlatul Ulama' Student Association Branch of Ponorogo Regency in Overcoming Radicalism. This study uses a qualitative approach which has the characteristics of direct data sources, the description is the delivery of communication patterns of the PC leadership of IPNU Ponorogo. The results of this study are the ways of the leadership of PC IPNU Ponorgo in warding off radicalism, namely by providing knowledge of the dangers of radicalism, especially for students through various media. Existing and existing activities in PC IPNU Ponorogo, besides that PC IPNU Ponorogo leaders also gave examples to cadres of tolerance and respect for traditions that already exist in Ponorogo district. And the communication patterns used are primary, secondary, literal, and circular communication. And there is also communication carried out by the leadership of the PC IPNU Ponorogo, namely by mass communication and group communication, this communication is carried out by providing information about
\end{abstract}




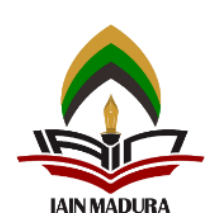

radicalism through seminars, studies and information obtained by PC IPNU Ponorogo leaders broadcast to IPNU cadres via the Whatss group app

\section{Keyword: Communication, leader, IPPNU, Radicalism}

\section{Pendahuluan}

Setelah era reformasi yang menandai dimulainya kebebasan di Indonesia, kelompok-kelompok Islam transnasional semakin kencang memanfaatkan situasi tersebut untuk mengembangkan ajarannya. Mereka menyasar para pemuda dan remaja di kampus atau sekolah menengah atas sebagai sasaran indoktrinasi ideologi radikalnya. Jika sebelumnya, proses tersebut berjalan secara sembunyi-sembunyi dengan sistem sel, sejak itu, rekrutmen anggota baru menjadi lebih terbuka. Menyasar generasi muda yang memiliki ghirah keislaman tinggi tetapi memiliki bekal pengetahuan agama minim.

Di Indonesia akhir-akhir ini banyak berkembang isu-isu radikalisme, di antaranya adalah kelompok yang mengklaim dirinya al-Qaeda dan ISIS, di mana keduanya menjadi isu global. ${ }^{1}$ Pada bulan September-November 2016, International NGO Forum on Indonesian Development (INFID) bekerja sama dengan Jaringan Gus Durian Indonesia melakukan dua kegiatan. Pertama, merekam persepsi anak muda terhadap radikalisasi agama dan ekstremisme dengan kekerasan melalui survei. Kedua, mengetahui narasi besar ekstremisme, memahami pesan-pesan kunci ekstremisme, dan mengetahui pola penyebaran pesan ekstremisme melalui pemetaan internet dan media sosial.

Pada awal abad ke-20, dalam peningkatan semangat dan ekonomi kian parah di kalangan pribumi, radikalisme muslim diambil alih oleh kelompok

${ }^{1}$ Christina Parolin, Radical Spaces: Venues of Popular Politicts in London, (Australia: ANU E Press, 2010), h. 3.
Serikat Islam (SI). ${ }^{2}$ Ikatan Pelajar Nahdlatul Ulama (IPNU) adalah salah satu organisasi di bawah naungan jam'iyah Nahdlatul Ulama, tempat berhimpun dan wadah komunikasi putraputri NU, merupakan bagian integral dari potensi generasi muda Indonesia yang menitikberatkan bidang garapannya pada pembinaan dan pengembangan pelajar, remaja dan santri. ${ }^{3}$

Dalam hal ini Pimpinan Cabang Ikatan Pelajar Nahdlatul Ulama' (IPNU) Kabupaten Ponorogo sebagai salah satu organisasi kepemudaan yang beranggotakan Pelajar, menggunakan pola komunisasi Dua Arah, guna membentengi para anggota dan pelajar terhadap faham Radikalisme yang saat ini membidik generasi muda untuk mengikuti faham radikal khususnya di wilayah Kabupaten Ponorogo.

Para kader dan pelajar yang ada di Kabupaten Ponorogo perlu memahami bahaya radikalisme. Beberapa hal yang perlu di waspadai semua pelajar dan generasi muda, Menurut pendapat Ahmad Rubaidi ${ }^{4}$ dalam bukunya yang berjudul Radikalisme Islam, Nahdatul Ulama Masa depan Moderatisme Islam di Indonesia menguraikan lima ciri gerakan Radikalisme diantarnya adalah sebagai berikut, 1) Menjadikan Islam sebagai ideologi final dalam mengatur kehidupan individual dan juga politik ketata negaraan. 2) Nilai-nilai Islam yang dianut

\footnotetext{
2 Khamami Zada, Islam Radikalisme, (Jakarta: Teraju, 2002), h. 87.

3 Soelaiman Fadeli, Antologi NU: Sejarah, Istilah, Amalia, Uswah, (Surabaya: Khalista, 2007), h. 52.

4 Zuly Qodir, Radikalisme Agama di Indonesia, (Yogyakarta: Pustaka Pelajar, 2014), h. 63.
} 
mengadopsi sumbernya di Timur Tengah secara apa adanya tanpa mempertimbangkan perkembangan sosial dan politik ketika al-Qur'an dan Hadis hadir di muka bumi ini dengan realitas lokal kekinian. 3) Faktor perhatiannya lebih terfokus pada teks alQur'an dan Hadis, maka purifikasi ini sangat berhati-hati untuk menerima segala budaya non asal Islam (budaya Timur Tengah) termasuk berhati-hati menerima tradisi lokal karena khawatir mencampuri Islam dengan bid'ah. 4) Menolak ideologi Non-Timur Tengah termasuk ideologi Barat, seperti demokrasi, sekularisme dan liberalisasi. Sekali lagi, segala peraturan yang ditetapkan harus merujuk pada al-Qur'an dan Hadis. 5) Gerakan kelompok ini sering berseberangan dengan masyarakat luas termasuk pemerintah. Oleh karena itu, terkadang terjadi gesekan ideologis bahkan fisik dengan kelompok lain, termasuk pemerintah.

Dikutip dari news.okezon.com dikatakan bahwa Dalam halaman 16, buku berjudul Anak Islam Suka Membaca ini, dituliskan karena suka cita rela mati bela agama. Kalimat ini dinilai tidak sejalan dengan ajaran Islam, karena tidak ada ajaran dalam Islam tentang membela agama yang mengarah ke kematian. Disinyalir, buku ini mengenalkan faham sesat kepada siswa. Hal ini sangat memprihatinkan karena terjadi di kalangan pelajar penyesatan lewat buku pelajaran yang seharusnya memberikan edukasi yang baik kepada pelajar.

\section{Pola Komunikasi}

Pola komunikasi merupakan serangkaian dua kata, karna keduanya mempunyai keterkaitan makna sehingga mendukung akan makna lainnya. Agar lebih jelasnya dua kata tersebut akan diuraikan tentang penjelasannya masing masing.

Kata "pola" dalam Kamus Besar Bahasa Indonesia (KBBI), artinya bentuk atau sistem, cara atau bentuk (struktur) yang tepat, yang mana pola dapat dikatakan contoh atau cetakan. ${ }^{5}$

Pola juga dapat diartikan bentuk atau cara untuk menunjukan suatu objek yang mengandung kompleksitas proses di dalamnya dan hubungan antar unsur pendukungnya. ${ }^{6}$ Sedangkan istilah komunikasi berasal dari bahasa latin "communicatos" yang berarti berbagi atau menjadi milik bersama. Kata sifatnya communis yang bermakna umum atau bersama sama. ${ }^{7}$

Menurut Webster new collegiate dictionary komunikasi adalah suatu proses pertukaran informasi diantara individu melalui sistem lambang lambang, tanda tanda atau tingkah laku. ${ }^{8}$

Everett M. Rogers seorang pakar sosiologi pedesaan amerika mengemukakan bahwa" komunikasi adalah proses dimana suatu ide dialihkan dari sumber kepada satu penerima atau lebih, dengan maksud untuk mengubah tingkah laku mereka”.

Definisi ini kemudian dikembangkan oleh rogers bersama D. Lawrence Kincaid (1981) sehingga melahirkan suatu definisi baru yang menyatakan bahwa "Komunikasi adalah suatu proses dimana dua orang atau lebih membentuk atau melakuan pertukaran informasi dengan satu sama lainnya, yang pada gilirannya akan tiba pada saling pengertian yang mendalam. ${ }^{9}$

\footnotetext{
5 Departemen Pendidikan dan Kebudayaan, Kamus Besar bahasa Indonesia, (Jakarta: Balai Pustaka, 1996), h. 778.

6 Wirianto, Pengantar Ilmu Komunikasi (Jakarta: Gramedia, 2004), h. 9.

${ }^{7}$ Marhaeni Fajar, Ilmu Komunikasi \& Praktik (Yogyakarta: Graha ilmu, 2009), h. 31.

8 Riswandi, Ilmu Komunikasi, (Yogyakarta: Graha Ilmu, 2009), h. 1.

9 Hafied Cangara, Pengantar Ilmu Komunikasi, (Jakarta: Rajawali Pers, 2004), h. 22.
} 
Menurut effendi yang di maksud dengan pola komunikasi adalah proses yang dirancang untuk mewakili kenyataan keterpautan unsur unsure yang dicakup beserta keberlangsungannya, guna memudahkan pemikiran secara sistematik dan logis. ${ }^{10}$

Dari pengertian pengertian diatas penulis mengambil kesimpulan bahwa pola komunikasi adalah gambaran dua orang atau lebih dalam proses pengiriman dan penerimaan pesan dengan tepat, sehingga pesan yang di maksud dapat tersampaikan atau dapat mudah dipahami. Dengan demikian dapat diuraukan bahwa proses komunikasi tersebut dapat dikatagorikan pola komunikasi seperti berikut:

Pola komunikasi primer, pola komunikasi primer merupakan suatu proses penyampaian pikiran oleh komunikator kepada komunikasi dengan menggunakan suatu lambang sebagai media maupun saluran, baik secara verbal maupun non verbal. ${ }^{11}$

Proses komunikasi primer menggunakan lambang bahasa yaitu proses komunikasi yang paling banyak digunakan, karna bahasa mampu mengungkapkan pikiran komunikator kepada komunikan secara baik.

Pola komunikasi sekunder, proses komunikasi secara sekunder adalah proses penyampaian pesan oleh komunikator kepada komunikan dengan menggunakan alat atau sarana sebagai media kedua setelah memakai lambang sebagai media pertama. ${ }^{12}$

10 Onong Uchjana Effendy, Dinamika Komunikasi, (Bandung: PT Remaja Rosdakarya, 1993), h. 30.

11 Ibid., h. 31.

12 Deddy Mulyana, Ilmu Komunikasi Suatu Pengantar, (Bandung: PT. Remaja Rosdakarya, 2010), h. 260
Komunikator menggunakan kedua media ini karna komunikan yang dijadikan sasaran komunikasinya jauh tempatnya atau banyak jumlahnya, atau keduaya jauh dan banyak. Komunikasi dalam proses secara sekunder ini senakin lama semakin efektif dan efisien karna didukung oleh teknologi komunikasi yang semakin canggih, yang ditupang pula oleh teknologi tenologi yang bukan tenologi komunikasi. ${ }^{13}$

Seperti yang sudah dijelaskan sebelumnya bahwa pada umumnya bahasa adalah yang paling banyak digunakan dalam komunikasi karna bahasa sebagai lambang mampu mentransisikan pikiran, ide, pendapat dan sebagainya baik hal abstrak maupun yang kongkrit. Namun pada akhirnya berjalan dengan perkembangan masyarakat, komunikasi mengalami kemajuan dengan memadukan berlambang bahasa dengan memadukan dengan komunikasi berlambang warna dan warna.

Pola komunikasi linear, istilah linear mengandung makna lurus. Jadi proses linear berarti perjalanan dari suatu titik ketitik yang lain secara lurus. Dalam konteks komunikasi, proses liniar adalah proses penyampaian pesan oleh komunikator kepada komunikan sebagai titik terminal. Komunikasi linear ini berlangsung dengan baik dalam situasi komunikasi tatap muka (face to face comunikation) maupun dalam situasi bermedia (mediated communication). ${ }^{14}$

Pola komunikasi silkular, silkular sebagai terjemah dari perkataan "cilcular" secara harfiah berarti bulat, bundar dan keliling sebagai lawan dari kata linear tadi yang bermakna lurus. Dalam konteks komunikasi yang dimaksud dengan proses komunikasi silkular adalah

\footnotetext{
13 Ibid., h. 261.

${ }^{14}$ Ibid., h. 38.
} 
IAINMADURA

terjadinya feedback atau umpan balik, yaitu terjadinya arus dari komunikan kepada komuniator. Oleh karna itu ada kalanya feedback tersebut mengalir dari komunikan kepada komunikator itu adalah "response" atau tanggapan komunikan terhadap pesan yang iya terima dari komunikator. ${ }^{11}$

Jadi pola komunikasi silkular adalah terjadinya feedback atau umpan balik antara komunikan kepada komunikator, begitupun sebaliknya, dan saling memberikan tanggapan antara komunikator dan komunikan tersebut terhapat pesan yang disampaikan dari komunikan terhadap komunikator.

Joseph A. Devito membagi pola komunikasi menjadi empat, yakni komunikasi dengan diri sendiri, komunikasi antarpribadi, komunikasi kelompok dan komunikasi massa. ${ }^{15}$

Komunikasi dengan diri sendiri. Ada tanda tanda umum sesuatu bisa dikatakan komunikasi dengan diri sendiri, yaitu keputusan merupakan hasil pemikiran dan hasil usaha intelektual, keputusan selalu melibatkan pilihan dari berbagai alternatif, keputusan selalu melibatkan tindakan nyata, walaupun pelaksanaannya boleh ditangguhkan atau dilupakan. ${ }^{16}$

Komunikasi antar pribadi, Menurut sifatnya, komunikasi anatar personal dibedakan menjadi dua, yaitu komunikasi diadik (dyadic communication) dan komunikasi kelompok kecil (small group communication). Komunikasi diadik adalah proses komunikasi yang berlangsung antara dua orang dalam situasi tatap muka melalui bentu percakapan, dan dialog. Adapun komunikasi kelompok kecil adalah proses komunikasi yang berlangsung antara tiga orang atau lebih secara tatap muka hal mana anggota anggotannya berinteraksi satu sama lain. Mengenai batas jumlah anggota tidak secara langsung disebutkan. Ada yang mengatakan biasannya antara 2-3 orang. ${ }^{17}$

Komunikasi kelompok, Dalam komuniasi kelompok kita mengenal seminar, diskusi panel, pidato, rapat akbar, pentas seni tradisional di desa, pengarahan dan ceramah dengan kelompok besar. Dengan kata lain komunikasi sosial antara tempat, situasi dan sasarannya jelas. ${ }^{18}$ Komunikasi kelompok adalah komunikasi yang dilakukan disuatu tempat dan dengan banyak orang atau kelompok yang besar dan dengan tujuan yang jelas.

Komunikasi massa, secara ringkas komunikasi massa bisa diartikan sebagai komunikasi dengan menggunakan media massa, tentunnya media massa ini adalah media massa modern. Oleh karna itu media tradisional tidak dimasukan dalam istilah ini. ${ }^{18}$ Komunikasi massa adalah komunikasi yang dilakukan dengan media sosial, dengan menyampaikan informasi dengan orang banyak dengan media massa, sepeti tv, radio dan sebagainya.

Menurut Onong Uchjana Effendi proses komunikasi terbagi menjadi dua yaitu proses komunikasi primer dan proses komunikasi sekunder.

Proses komunikasi secara primer ialah proses penyampaian pikiran dan atau perasaan seseorang kepada orang lain dengan menggunakan lambang (simbol) sebagai media. Lambang sebagai media dalam proses komunikasi secara primer adalah bahasa, isyarat, gambar,warna dan lain sebagainya yang secara langsung mampu menterjemahkan pikiran atau

15 Nurudin, Sistem Komunikasi Indonesia, (Jakarta: Rajawali Pers, 2012), h. 28.

16 Ibid., h. 30.

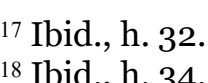




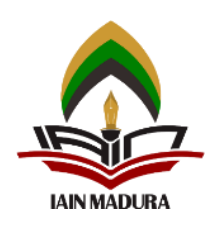

perasaan komunikator

kepada komunikan. ${ }^{19}$

Proses komunikasi primer menggunakan lambang bahasa adalah proses komunikasi yang paling sering digunakan, karna bahasa mampu mengungkapkan pikiran atau tujuan komunikator kepada komunikan, serta ada feedback antara komunikator dan komunikan.

Proses komunikasi secara sekunder ialah proses penyampaian pesan oleh seseorang kepada orang lain dengan menggunakan alat atau sarana sebagai media kedua setelah memakai lambang sebagai media pertama. ${ }^{26}$

Dalam proses komunikasi sekunder seorang komunikator menggunakan media dalam melancaran komunikasinya karna komunikan berada di tempat yang jauh sehingga menggunakan telepon dan surat kabar.

Pola komunikasi merupakan model dari proses komunikasi, sehingga dengan adanya berbagai macam model komunikasi dan bagian dari proses komunikasi akan dapat di temukan pola yang cocok dan mudah di gunakan dalam berkomunikasi. Pola komunikasi identik dengan proses komunikasi, karena pola komunikasi merupakan rangkaian dari aktivitas menyampaikan pesan sehingga di peroleh feedback dari penerimaan pesan. Dari proses komunikasi, akan timbul pola, model, bentuk, dan juga bagian-bagian kecil yang berkaitan erat dengan proses komunikasi. ${ }^{20}$

Model Komunikasi adalah gambaran yang sederhana dari proses komunikasi yang memperlihatkan kaitan antara satu komponen komunikasi dengan

\footnotetext{
${ }_{19}$ Onong Uchjana Effendy, Ilmu Komunikasi Teori dan Praktek, (Bandung: Remaja Rosdakarya, 2009), h. 11.

20 Onong Uchayana Effendy, Dinamika Komunikasi...., h. 33 .
}

komponen lainnya. ${ }^{21}$ Menurut Gorden Wiseman dan Larry Barker mengemukakan bahwa ada tiga fungsi model komunikasi yang pertama melukiskan proses komunikasi, kedua, menunjukkan hubungan visual, dan ketiga, membantu dalam menemukan dan memperbaiki kemacetan komunkasi. ${ }^{22}$

Terdapat ratusan model-model komunikasi yang telah di buat para pakar. Kekhasan suatu model komunikasi juga di pengaruhi oleh latar belakang keilmuan (pembuat) model tersebut, paradigm yang digunakan, kondisi teknologis, dan semangat zaman yang melengkapinya. Dibawah ini modelmodel komunikasi yang sangat popular. pertama, Model Stimulus respons (S - R) adalah model komunikasi paling dasar. Model ini di pengaruhi oleh disiplin psikologi, khususnya yang beraliran behavioristic. Model tersebut menggambarkan hubungan stimulus respons.

Model pada gambar 2.1 menunjukkan komunikasi sebagai proses aksi reaksi yang sangat sederhana. Model S-R mengabaikan komunikasi sebagai suatu proses, khususnya yang berkenaan dengan factor manusia. Secara implisit ada asumsi dalam model S-R ini bahwa perilaku (respons) manusia dapat diramalkan. Ringkasnya, komunikasi di anggap statis, manusia di anggap berprilaku karena kekuatan dari luar (stimulus), bukan berdasarkan kehendak, keinginan, atau kemampuan bebasnya. Model ini lebih sesuai bila di terapkan pada sistem pengendalian suhu udara alih-alih pada prilaku manusia. ${ }^{23}$

\footnotetext{
${ }^{21}$ Arni Muhammad, Komunikasi Organisasi, (Jakarta: Bumi Aksara, 1992), h. 5.

22 Ardianto, Komunikasi Massa Suatu Pengantar, (Bandung: Simbiosa Rekatama Media, 2007), h. 68.

23 Deddy Mulyana, Ilmu Komunikasi, (Bandung: PT. Remaja Rosdakarya, 2005), h. 134.
} 
Kedua, Model Aristoteles (gambar 2.2) adalah model komunikasi paling klasik, yang sering juga disebut model retoris (rhetorical model). Ia berjasa dalam merumuskan model komunikasi verbal pertama. Komunikasi terjadi ketika seorang pembicara menyampaikan pembicaraannya kepada khalayak dalam upaya mengubah sikap mereka. Tepatnya ia mengemukakan tiga unsur dalam proses komunikasi, yaitu pembicara (speaker), pesan (message), dan pendengar (listener).

Seperti model S-R, model komunikasi Aristoteles jelas sangat sederhana, malah terlalu sederhana di pandang dari perspektif sekarang, karena tidak memuat unsur-unsur lainnya yan di kenal dalam model komunikasi, seperti saluran, umpan balik, efek, dan kendala atau gangguan komunikasi. Salah satu kelemahan model ini adalah bahwa komunikasi dianggap fenomena yang statis. Seseorang berbicara, pesannya berjalan kepada khalayak, dan khalayak mendengarkan. Tahap-tahap dalam peristiwa itu berurutan ketimbang terjadi secara simultan. Di samping itu model ini juga berfokus pada komunikasi yang bertujuan (disengaja) yang terjadi ketika seseorang berusaha membujuk orang lain untuk menerima pendapatnya. ${ }^{24}$

\section{Radikalisme}

Secara etimologi, radikalisme dengan kata dasar radikal berasal dari bahasa Latin, radix, yang berarti "akar". Radikalisme merupakan respons terhadap kondisi yang sedang berlangsung yang muncul dalam bentuk evaluasi, penolakan, atau bahkan perlawanan terhadap ide, asumsi, kelembagaan, atau nilai. ${ }^{25}$

${ }^{24}$ Ibid., h. 36.

25 Dede Rodin, "Islam Dan Radikalisme: Telaah atas Ayat-ayat 'Kekerasan' dalam alQur'an," Jurnal Addin, Vol. 10, No. 1.
Terminologi radikalisme agama jika dikaitkan dengan istilah bahasa Arab, sampai saat ini belum ditemukan secara pasti dalam kamus-kamus bahasa Arab. Sehingga istilah ini sering dikaitkan dengan fundamentalisme Islam yang berasal dari teori Barat. ${ }^{26}$

Radikalisme merupakan suatu paham yang menghendaki adanya perubahan, pergantian, dan penjebolan terhadap suatu sistem masyarakat sampai ke akarnya. Radikalisme menginginkan adanya perubahan secara total terhadap suatu kondisi atau semua aspek kehidupan masyarakat. Kaum radikal menganggap bahwa rencana-rencana yang digunakan adalah rencana yang paling ideal. Terkait dengan radikalisme ini, seringkali beralaskan pemahaman sempit agama yang berujung pada aksi terror bom tumbuh bersama sistem. Sikap ektrem ini berkembang biak di tengah tengah panggung yang mempertontonkan kemiskinan, kesenjangan sosial, atau ketidakadilan. ${ }^{27}$ Perilaku kekerasan merupakan respons terhadap kegagalan atau tatanan sosiopolitik yang ada. Kelompok pelaku kekerasan berupaya agar ideologi mereka menjadi satu-satunya alternatif yang dapat menggantikan tatanan yang ada. Harapannya adalah dapat mengentaskan manusia dari modernitas yang membuatnya tercerabut dari nilai-nilai agama. Amarah yang diekspresikan dengan kekerasan adalah reaksi terhadap kondisi-kondisi sosial tertentu yang diketahui dapat diubah menjadi lebih baik, namun tidak dilakukan perubahan untuk itu. Oleh karena itu, muncullah ideologi “dunia ketiga”. Dalam konteks gerakan Islam "radikal", ideologi penyatuan dunia Islam dalam naungan

26 Junaidi Abdillah, "Dekonstruksi Tafsir Ayat-Ayat 'Kekerasan' dalam Al-Qur'an,” Jurnal Kalam: Studi Agama dan Pemikiran Islam, Vol. 8.

${ }^{27}$ Zuly Qodir, Radikalisme Agama...., h. 117. 


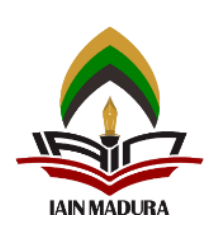

Khilafah Islamiyah, sesungguhnya juga muncul sebagai respons terhadap ideologi-ideologi modern yang tidak mampu menyelesaikan permasalahan hidup manusia.

Secara internal agama, fenomena kekerasan agama bisa terjadi karena merupakan respons terhadap penyimpangan ajaran agama yang dilakukan oleh sekelompok orang. Oleh karena itu, dalam perspektif kelompok tertentu, jalan kekerasan harus dilakukan untuk memaksa dalam rangka melakukan pemurnian kembali agama yang telah terasuki penyakit tahayul, bid"ah dan khurafat. ${ }^{28}$

Sartono Kartodirdjo mengartikan radikalisme sebagai gerakan sosial yang menolak secara menyeluruh tertib sosial yang sedang berlangsung dan ditandai oleh kejengkelan moral yang kuat untuk menentang dan bermusuhan dengan kaum yang memiliki hak-hak istimewa dan yang berkuasa. ${ }^{29}$

Rubaidi menguraikan lima ciri gerakan radikalisme Islam.Pertama, menjadikan Islam sebagai ideologi final dalam mengatur kehidupan individual dan juga politik ketata negaraan. Kedua, nilai-nilai Islam yangdianut mengadopsi sumbernya di Timur Tengah secara apa adanya tanpa mempertimbangkan perkembangan sosial dan politik ketika Al-Qur'an dan Hadis hadir di muka bumi ini, dengan realitas lokal kekinian. Ketiga, karena perhatian lebih terfokus pada teks alQur'an dan Hadis, maka purifikasi ini sangat berhati-hati untuk menerima segala budaya tidak berasal dari Islam termasuk berhati-hati menerima tradisi lokal karena khawatir mencampuri Islam dengan bid'ah. Keempat, menolak ideologi Non-Timur Tengah termasuk

28 Agus Purnomo, Ideologi Kekerasan: Argumentasi Teologis-Sosial Radikalisme Islam, (Yogyakarta: Pustaka Pelajar, 2009), h. 36-37.

29 Sartono Kartodirdjo, Ratu Adil, (Jakarta: Sinar Harapan, 1985), h. 38. ideologi Barat, seperti demokrasi, sekularisme dan liberalisasi. Sekali lagi, segala peraturan yangditetapkan harus merujuk pada al-Qur'an dan Hadis. Kelima, gerakan kelompokini sering berseberangan dengan masyarakat luas termasuk pemerintah. Olehkarena itu, terkadang terjadi gesekan ideologis bahkan fisik dengan kelompok lain,termasuk pemerintah. ${ }^{30}$

Persoalan muncul ketika sebuah kelembagaan atau institusi mengusung nilai-nilail ke-Islam-an kaffah dengan sarana yang mengundang respon negatif masyarakat. Semisal dengan adanya tindakan anarki kepada komunitas yang di nilai tidak Islami. Tindakan-tindakan yang secara sepihak oleh komunitas tersebut di anggap sebagai tindakan positif, justru memunculkan image negatif di mata masyarakat. Satu contoh sebagaimana di ketahui bersama teror bom dalam bentuk peledakan bom sebagaimana terjadi di Bali ${ }^{31}$, kemudian pengrusakan terhadap kafe-kafe dan diskotik dibeberapa daerah. Timbulnya salah pengertian tentang Islam oleh sebagian kaum muslim, termasuk mempersepsikan Islam dengan kekerasan atau terorisme, sejak dulu kala sampai sekarang tidak saja dipengaruhi oleh pemahaman dan pemikiran positivistik (legal formal). Suatu metode pemikiran yang melihat persoalan interaksi sosial kompleks hanya dilihat dari segi tekstual, halal, haram, hak, dan kewajiban.

Konsekuensi dari model pemikiran ini adalah menjadikan sebagian umat Islam tidak mampu membedakan antara mana yang merupakan esensi ajaran Islam, dan

30 A. Rubaidi, Radikalisme Islam, Nahdlatul Ulama; Masa Depan Moderatisme Islam di Indonesia, (Yogyakarta: Logung Pustaka, 2010), h. 63 .

31 Rusdi Marpaung dan Al Araf, Terorisme Definisi Aksi dan Regulasi, (Jakarta: Imparsial. 2003), h. 37. 
mana pula yang tergolong budaya lokal atau Arab. ${ }^{32}$

Implikasinya terhadap bangsa kita yang berpenduduk mayoritas Islam, khususnya di kalangan organisasi-organisasi Islam seperti Front Pembela Islam (FPI) dan Majelis Mujahidin Indonesia (MMI), dsb secara terbuka memberi reaksi 'keras' terhadap AS Negara adidaya atas intervensi konflik timur tengah (membantu Israel). Betapa konflik Palestina 'di nilai mewakili Islam, dan Israel mewakili 'Nasrani dan Yahudi'. Rasa kemarahan dan kebencian terhadap Zionis Israel, AS dan sekutunya, telah dirasuk sejak tahun 1967, di mana secara historis keuntungan atau kemenangan selalu berada di pihak Israel. Apalagi dengan adanya intervensi-pendudukan pasukan Amerika Serikat (pembebasan Kuwait, penangkapan presiden Sadham Husein dan para teroris yang terkait dengan jaringan al-Qaida/Taliban (Osama Bin Landen) atas seluruh wilayah Irak dan Afganistan sampai sekarang ini. Rasukan kemarahan dan kebencian ini akhirnya mengkristal menjadi ideologi solidaritas primordialisme bagi kelompok-kelompok radikal Islam yang tersebar baik di Timur Tengah (Arab Saudi, Libanon, Siria, Irak); di Arika (Mesir, Libia, Sudan, Maroko, Aljazair) maupun di Asia (Afganistan, Iran, Malaysia dan Indonesia).

Khususnya konflik Palestina - Israel, apabila dilihat secara objektif sesungguhnya bukan konflik agama, melainkan persoalan teritori atau wilayah yang terjadi sejak Inggris memprakarsai kemerdekaan Zionis Israel pada tahun 1947. Lagi pula pejuangpejuang Palestina bukan hanya kaum Muslim tapi juga ada yang beragama Kristen (salah seorang tokoh radikalnya, George Habbash adalah seorang Kristen

32 Thontowi, Jawahir, Islam Neo imperalialisme dan Terorisme, (Yogyakarta: UII Press. 2004), h. 15.
Ortodoks-Yunani), makanya tidak mengherankan kota Betlehem tempat kelahiran Tuhan Jesus Kristus oleh Israel diserahkan kepada Palestina (Arab Kristen) menjadi bagian wilayah otonominya.

Menurut pendapat Ahmad Rubaidi dalam bukunya yang berjudul Radikalisme Islam, Nahdatul Ulama Masa depan Moderatisme Islam di Indonesia menguraikan lima ciri gerakan Radikalisme diantarnya adalah: Menjadikan Islam sebagai ideologi final dalam mengatur kehidupan individual dan juga politik ketata negaraan, nilainilai Islam yang di anut mengadopsi sumbernya di Timur Tengah secara apa adanya tanpa mempertimbangkan perkembangan sosial dan politik ketika al-Qur'an dan Hadis hadir di muka bumi ini dengan realitas lokal kekinian. Faktor perhatiannya lebih terfokus pada teks alQur'an dan Hadis, maka purifikasi ini sangat berhati-hati untuk menerima segala budaya non asal Islam (budaya Timur Tengah) termasuk berhati-hati menerima tradisi lokal karena khawatir mencampuri Islam dengan bid'ah. Menolak ideologi Non-Timur Tengah termasuk ideology Barat, seperti demokrasi, sekularisme dan liberalisasi. Sekali lagi, segala peraturan yang ditetapkan harus merujuk pada al-Qur'an dan Hadis. Gerakan kelompok ini sering berseberangan dengan masyarakat luas termasuk pemerintah. Oleh karena itu, terkadang terjadi gesekan ideologis bahkan fisik dengan kelompok lain, termasuk pemerintah. ${ }^{33}$

M. Dawam Raharjo mengemukakan 4 hipotesis yang melatar belakangi berkembangnya Islam radikal di Indonesia, yaitu: Pengaruh gerakangerakan Islam transnasional seperti Ikhwan al-Muslimin, Hizbut Tahrir, Wahabisme Saudi Arabia, Islam Taliban, dan Al-Qaeda, yang semuanya mencita-

\footnotetext{
${ }^{33}$ Zuly Qodir, Radikalisme Agama...., h. 26.
} 
citakan tegaknya syariat Islam di semua bidang kehidupan. Pengaruh euphoria demokratisasi di Indonesia, yang dimaknai sebagai peluang bagi munculnya gerakan-gerakan Islam radikal yang pada masa Orde Baru dibungkam dan dipaksa tiarap oleh pemerintahan yang otoriter sekuler. Gagalnya penegakan negara hukum demokratis, sehingga menimbulkan kembali inspirasi untuk menegakkan syariat Islam, sesuatu yang pada dasarnya bertolak belakang dengan sistem hukum demokratis yang sekuler. Gagalnya gerakan dakwah yang rahmatan li ' $l$ 'ālamin, yang toleran terhadap keyakinan beragama yang berbeda-beda dan bersifat inklusif. Berkembangnya gerakan dakwah yang eksklusif dan intoleransi terhadap keragaman. ${ }^{34}$

\section{Hasil dan Pembahasan Pola Komunikasi}

IPNU merupakan organisasi yang berada di bawah naungan NU yang menekankan pada prinsip dasar atau ideologi Ahlus sunnah wal Jamaah, dalam prinsip atau ideologi tersebut dijelaskan oleh ketua PC IPNU Ponorogo bahwa IPNU ber-ideologi Islam ahlus sunnah wal jama'ah annahdliyah, didirikan dengan ta'ādul (keadilan), tawāzun (keseimbangan), tasāmuh (toleransi), tawassuth (moderat), dan islāhiyah (perbaikan). Tasamuh itu toleran, tawasuth ya itu tadi moderat. Kader IPNU itu punya tugas untuk memelihara ideologi- ideologi islam yang moderat, islam yang tasamuh toleran dan karena mempertahankan, melestarikan dan mengembnagkan berarti juga dalam berdakwah itu misinya itu mengembangkan islam yang moderat, Islam yang toleran.

34 Baca: M. Dawam Raharjo, "Fanatisme dan Toleransi", pengantar dalam Irwan Masduqi, Berislam Secara Toleran, (Bandung: Mizan, 2011), h. xxvii.
Melalui prinsip ideologi ASWAJA, IPNU selalu mengambil posisi sikap akomodatif, toleran dan menghindari sikap ekstrim dalam ketika berhadapan dengan spektrum budaya dari luar. Prinsip ideologi ASWAJA mencerminkan sikap IPNU yang selalu dikalkulasikan atas dasar pertimbangan hukum yang bermuara pada aspek maslahah dan mafsadah. Fikrah Nahdliyah yang memuat nilai ASWAJA itu menempatkan kedamaian sebagai misi Islam.

Secara teori IPNU beraqidahkan Islam Ahlussunnah wal Jama'ah yang berhaluan pada salah satu dari Mahdzab Empat, yaitu Imam Syafi'i, Maliki, Hambali dan Hanafi, Dalam kehidupan berbangsa dan bernegara, IPNU berdasarkan kepada Pancasila, dan IPNU adalah organisasi yang bersifat keterpelajaran, kekaderan, kekeluargaan, kemasyarakatan, kebangsaan dan keagamaan. Tujuan dibentuknya IPNU adalah untuk terpeliharanya rasa kekeluargaan pelajar-pelajar di pesantren, madrasah, sekolah umum dan mahasiswa yang sehaluan. ${ }^{35}$ Tujuan lainnya adalah agar terbentuknya pelajar bangsa yang bertaqwa kepada Allah Subhanallahu Wa Ta'ala, berilmu, berakhlak mulia, berwawasan kebhinekaan serta bertanggung jawab atas terlaksananya syari'at Islam Ahlussunnah wal Jama'ah yang berdasarkan pancasila dan UndangUndang Dasar 1945 demi tegaknya NKRI. ${ }^{36}$

Dari data dan teori diatas bahwa IPNU Merupakan organisasi pelajar dengan berideologi ahlus sunah wal jamaah yang menjadi dasar kader PC IPNU Ponorogo dalam kehidupan berbangsa dan bernegara.

35 Tolchah Mansoer, Sambutan Ketua Umum P. P IPNU dalam Buku Panduan Muktamar I IPNU, (Malang: Panitia Muktamar I, 1955), h. 5.

36 Arsip Museum NU, "Anggaran Dasar IPNU pada Muktamar ke III”. 
Dengan paham ASWAJA IPNU menjadi pilar penyangga bangsa dikalangan pelajar terlebih untuk menangkal paham radikalisme, paham radikalisme yang ada di Indonesia sekarang ini sudah tersebar lewat berbagai macam media online maupun offline. Paham radikalisme sangat tidak baik untuk keberlangsungan bangsa khususnya untuk kaum pelajar, pelajar yang belum begitu memahami tentang apa itu radikalisme sangat mudah untuk dipengaruhi oleh para pendakwah faham radikalisme, hal ini diungkapkan apa yang diungkapkan oleh ketua IPNU Paham radikalisme menurutnya faham radikalisme sangat berbahaya khususnya untuk para kaum pelajar apalagi dengan bebasnya informasi di era digital ini sehingga perlu cara tersendiri untuk memahamkan apa itu radikalisme kepada kaum pelajar dari cara memberikan pelajaran akan sejarah Islam, pemahaman keagamaan yang tidak setengah-setengah.

Secara teori penyebab faham radikalisme menurut Azyumardi Azra, di kalangan Islam, radikalisme keagamaan itu banyak bersumber dari, Pemahaman keagamaan yang literal, sepotong-sepotong terhadap ayat-ayat al-Qur'an. Pemahaman seperti itu hampir tidak memberikan ruang bagi akomodasi dan kompromi dengan kelompok-kelompok muslim lain yang umumnya moderat, dan karena itu menjadi arus utama (mainstream) umat. Kelompok umat Islam yang berpaham seperti ini sudah muncul sejak masa alKhulafa' al-Rasyidun keempat Ali ibn Abi Thalib dalam bentuk kaum Khawarij yang sangat radikal dan melakukan banyak pembunuhan terhadap pemimpin muslim yang telah mereka nyatakan 'kafir'.

Bacaan yang salah terhadap sejarah Islam yang dikombinasikan dengan idealisasi berlebihan terhadap Islam pada masa tertentu. Ini terlihat dalam pandangan gerakan Salafi, khususnya pada spektrum sangat radikal seperti Wahabiyah yang muncul di Semenanjung Arabia pada akhir abad 18 awal sampai dengan abad 19 dan terus merebak sampai sekarang ini. Tema pokok kelompok dan sel Salafi ini adalah pemurnian Islam, yakni membersihkan Islam dari pemahaman dan praktek keagamaan yang mereka pandang sebagai 'bid'ah', yang tidak jarang mereka lakukan dengan caracara kekerasan. Dengan pemahaman dan praksis keagamaan seperti itu, kelompok dan sel radikal ini 'menyempal' (splinter) dari mainstream Islam yang memegang dominasi dan hegemoni otoritas teologis dan hukum agama dan sekaligus kepemimpinan agama. Karena itu, respon dan reaksi keras sering muncul dari kelompok-kelompok 'mainstream', arus utama, dalam agama. Mereka tidak jarang mengeluarkan ketetapan, bahkan fatwa, yang menetapkan kelompokkelompok sempalan tersebut sebagai sesat dan menyesatkan. Ketetapan atau fatwa tersebut dalam prakteknya tidak jarang pula digunakan kelompokkelompok mainstream tertentu sebagai dasar dan justifikasi untuk melakukan tindakan main hakim sendiri.

Deprivasi politik, sosial dan ekonomi yang masih bertahan dalam masyarakat. Pada saat yang sama, disorientasi dan dislokasi sosial-budaya, dan ekses globalisasi, dan semacamnya sekaligus merupakan tambahan factor-faktor penting bagi kemunculan kelompokkelompok radikal. Kelompokkelompok sempalan tersebut tidak jarang mengambil bentuk kultus (cult), yang sangat eksklusif, tertutup dan berpusat pada seseorang yang dipandang kharismatik. Kelompok-kelompok ini dengan dogma eskatologis tertentu bahkan memandang dunia sudah menjelang akhir zaman dan kiamat; sekarang waktunya bertobat melalui pemimpin dan kelompok mereka. Doktrin dan pandangan teologiseskatologis seperti ini, tidak bisa lain dengan segera dapat menimbulkan reaksi 
dari agama-agama mainstream, yang dapat berujung pada konflik sosial. ${ }^{37}$

Dari data dan teori diatas bahwa penyebab faham radikalisme adalah pemahaman akan agama yang setengahsetengah dan juga pengetahuan akan sejarah Islam yang kurang, hal ini sangat rentan dimasuki oleh para pendakwah radikalisme karena para pelajar belum begitu memahami dengan betul apa yang agama dan sejarah Islam.

Pelajar yang pemikirannya belum luas akan pengalaman dan juga wawasannya perlu dipahamkan akan bahayanya faham radikalisme sehingga perlu cara tersendiri, organisasi IPNU adalah organisasi pelajar yang dapat menjadi tempat untuk para pelajar memahami bahayanya paham radikalisme, salah satunya adalah PC IPNU yang berada di Ponorogo. Seperti yang diungkapkan oleh ketua bidang bahwa mayoritas anggota PC IPNU Ponorogo adalah pelajar yang masih kurang dalam wawasan akan pengetahuan apa itu faham radikalisme jadi pelu adanya proses pembelajaran yang harus diberikan kepada anggota tentang faham radikalisme itu seperti apa dan bagaimana cara kerjanya contoh dengan memberikan seminar kebangsaan dan kajian-kajian rutin yang disitu dipahamkan betul akan pentingnya aswaja dan bahayanya radikalisme.

Tugas organisasi IPNU adalah mengkader dengan cara memberikan dan menumbuhkan ideologinya kepada anggotanya. Pada prinsipnya tugas organisasi dapat berjalan dengan baik karena adanya struktural pengurus yang menjadi satu kesatuan utuh dan di koordinir oleh pimpinan organisasi, sehingga roda organisasi dapat berjalan dengan baik. Dalam organisasi orang yang bertanggung jawab adalah pimpinannya di internal dan eksternal

37 Abdul Munip, "Menangkal Radikalisme Agama di Sekolah" Jurnal Pendidikan Islam (JPI), Vol. 1: 162-165. organisasi. Hal ini diungkapkan oleh sekretaris umum PC IPNU Ponorogo menjelaskan Organisasi akan berjalan dengan baik jika organisasi tersebut mempunyai satu kesatuan utuh dari pimpinan organisasi beserta pengurus dan anggota organisasi tersebut, dan pada hakikatnya yang bertanggung jawab sepenuhnya akan organisasi adalah pimpinan organisasi.

Anggota IPNU yang mauyoritas masih pelajar memberikan pekerjaan rumah tersendiri kepada PC IPNU khususnya pimpinan PC IPNU pasalnya usia pelajar yang masih rentan akan pemikirannya akan keingintahuan tinggi terhadap sesuatu membuat IPNU Cabang Ponorogomerupakan organisasi pelajar harus membentengi anggotanya dengan pemahaman akan bahayanya faham radikalisme. Seperti yang terlihat pada hari jumat IPNU Cabang Ponorogo mengadakan kajian tentang faham radikalisme yang dihadiri oleh anggotanya yang masih pelajar. Disampaikan juga oleh bidang kajian keilmuan selaku organisasi pelajar yang memegang teguh ahlussunah wal jamaah organisasi IPNU harus bisa membentengi dirinya dari faham radikalisme dengan menanamkan nilai-nilai ahlussunah wal jamaah seperti yang kita lakukan kemarin yaitu dengan mengadakan kajian yang bertemakan bahaya radikalisme terhadap penerus bangsa.

Dalam membentengi anggotanya dari faham radikalisme pimpinan lah yang bertanggung jawab selain organisasi pada umumnya. Pemipin dalam organisasi bertanggung jawab terhadap organisasi dan anggota organisasinya, begitu juga dalam membentengi anggotanya akan faham radikalisme. Seperti yang dikatakan oleh anggota Organisasi bagi saya adalah tempat saya mendapatkan ilmu tambahan jadi Ketika saya ikut organisasi saya harus mendapatkan ilmu dan wawasan yang lebih jika tidak maka yang saya salahkan ketuanya karena 
ketua yang paling bertanggung jawab di organisasi.

Pimpinan adalah uswatun hasanah apa yang menjadi tingkah lakunya akan di contoh anggotanya, dalam hal ini pimpinan PC IPNU Ponorogo memberikan contoh sikap toleransi kepada sesama dimulai dari toleransi dalam adat dan budaya, toleransi dalam adat dan budaya diwujudkan oleh pimpinan PC IPNU dengan berteman dengan siapapun dan dari manapun daerahnya tanpa membeda-bedakan. Hal ini diungkapkan oleh salah satu anggota PC IPNU Ponorogo bahwa di daerah Ponorogo ini penduduknya tidak hanya asli Ponorogo saja tetapi jug ada pendatang, pendatang biasanya ke Ponorogo untuk mondok dan sekolah, pendatang itu kan tidak hanya dari pulau jawa saja tapi ada juga dari luar pulau jawa, ada yang dari NTB, Kalimantan, Sumatra bahkan sampai Papua dan semua itu ada di organisasi IPNU ini, dan alhamdulillah pimpinan PC IPNU Ponorogo tidak membeda-bedakan mereka, mereka sudah dianggap saudara sendiri di organisasi ini.

Mengamalkan sikap toleransi yang diajarkan oleh pimpinan PC IPNU Ponorogo juga dibarengi dengan menghargai tradisi yang ada, contohkan tradisi yang dilakukan oleh pemerintah kabupaten Ponorogo yaitu grebek suro, dengan mengikuti setiap agenda yang ada pada grebek suro menunjukan bahwa kader PC IPNU Ponorogo menghargai tradisi yang sudah ada sejak dahulu dilakukan oleh pemerintah kabupaten Ponorogo. Hal ini dijelaskan oleh pimpinan PC IPNU Ponorogo Menghargai tradisi yang sudah ada sejak lama di pemerintah kabupaten Ponorogo khususnya ini adalah dengan ikut memeriahkan setiap deretan agenda acara yang ada, dengan itu kita selaku kader IPNU Ponorogo menanamkan nilai menghargai tradisi yang sudah ada.
Secara teori cara menangkal faham radikalisme menurut Imdadun Rahmat dalam "Islam Pribumi Mendialogkan Agama Membaca Realitas", Syarif mengemukakan lima gagasan dalam pribumusasi Islam yaitu:

Pertama Kontekstual, yaitu Islam dipahami sebagai ajaran yang terkait zaman dan tempat. Ini berarti bahwa Islam adalah suatu agama yang dinamis, terus memperbaharui diri, dan respon terhadap perubahan zaman, serta lentur dan mampu berdialog dengan kondisi masyarakat yang berbeda untuk melakukan adaptasi kritis, sehingga Islam bisa dinilai sebagai ajaran yang shahih $l i$ kulli zaman wa almakan (relevan dengan perkembangan zaman dan tempat).

Kedua Toleran, sikap toleran dalam beragama dan toleran terhadap perbedaan penafsiran dapat menumbuhkan kesadaran untuk bersikap. Hal tersebut dikarenakan konteks dan kultur keindonesiaan yang plural, menuntut pula pengakuan tulus bagi kesederajatan terhadap agama agama lain.

Ketiga Menghargai Tradisi, di sini suatu etika hendaknya mengacu pada zaman Rosul. Islam dibangun di atas penghargaan pada tradisi lama yang baik, karena sesungguhnya Islam tidak memusuhi tradisi lokal melainkan budaya tersebut dijadikan sebagai sarana dakwah Islam. Hal tersebut seperti yang dilakukan oleh Walisongo dalam penyebaran agama Islam di Indonesia.

Keempat Progresif, dengan perubahan terhadap praktik keagamaan dimana ia berada. Islam berarti harus siap dan lapang dada menerima tradisi pemikiran orang lain kendatipun berasal dari Barat. Hal tersebut seperti dicontohkan oleh Rosul dalam haditsNya yaitu "carilah ilmu walau sampai ke negeri China”

Kelima Membebaskan, di sini Islam sebagai suatu agama yang dapat menjawab problematika kemanusiaan yang ada secara universal tanpa 
membedakan agama dan etnik. Dengan semangat pembebasan tersebut, sebagai agama yang rahmatan lil 'alamin Islam harus siap melawan penindasan, kemiskinan, keterbelakangan, anarki sosial dan lain sebagainya. ${ }^{38}$

Dari data dan teori diatas bahwa PC IPNU Ponorogo dalam menangkal faham radikalisme adalah dengan cara memberikan pengetahuan dengan cara mengkaji lebih dalam tentang faham radikalisme lewat berbagai macam sarana kegiatan yang ada di PC IPNU Ponorogo yaitu seminar, kajian, dan diskusi, selain itu cara pimpinan PC IPNU Ponorogo dalam menangkal faham radikalisme adalah dengan memberikan contoh kepada kader IPNU Ponorogo bagaimana bersikap toleransi kepada siapapun dengan tidak memandang suku, agama dan ras.

Menghargai tradisi yang sudah ada di kabupaten Ponorogo yaitu grebek suro dilakukan oleh pimpinan PC IPNU Ponorogo adalah sebagai wujud menangkal faham radikalisme yang ada di pemerintah kabupaten Ponorogo juga memberikan pengetahuan kepada para kader yang masih pelajar untuk menghargai tradisi yang sudah ada sejak dulu dan menjadi rutinan.

\section{Menangkal Faham Radikalisme}

Komunikasi adalah hal yang paling penting dalam berorganisasi, khusunya bagi pimpinan organisasi, pimpinan merupakan ujung tombak organisasi. Komunikasi yang dilakukan oleh pimpinan PC IPNU Ponorogo yang merupakan ujung tombak kaderisasi di organisasi IPNU Ponorogo adalah dengan menerapkan komunikasi yang bermacam-macam. Menurut pimpinan PC IPNU Ponorogo komunikasi yang digunakan yaitu dengan cara lewat berbagai macam media, salah satunya

\footnotetext{
${ }^{38}$ Ibid., h. 51-52
}

adalah group-group yang ada di WA dan seringnya komunikasi face to face jika memang ada hal yang sifatnya penting seperti problem bangsa yang saat ini masih ramai dibicarakan yaitu faham radikalisme.

Hal ini juga ditegaskan oleh sekretaris PC IPNU Ponorogo bahwa komunikasi secara face to face adalah cara yang paling efektif dalam berkomunikasi contohnya dalam membahas problem bangsa terkait isu radikalisme yang merongrong generasi muda, apa dan bagaiamana solusi yang diberikan oleh pimpinan cabang terhadap faham radikalisme yang ada di Indonesia saat ini.

Pembahasan yang dilakukan oleh pimpinan secara face to face dengan para senior dan juga pengurusnya terkait solusi radikalisme akan di bawa ke rapat sehingga akan mengahasilkan sebuah keputusan apa yang akan di berikan oleh pimpinan kepada organisasi dan kepada anggota IPNU Ponorogo pada khususunya. Proses komunikasi demikan dilakukan agar tercapai tujuan organisasi. Hal ini diungkapkan oleh anggota IPNU Ponorogo, menurtunya setiap pemimpin mempunyai caranya dalam memimpin, baik dari segi berkomunikasi dengan para senior, pengurus dan juga anggotanya, dan itu semua demi kemaslahatan bersama dan demi tercapainya tujuan organisasi ini mas. Kita sebagai anggota juga diberi hak oleh pimpinan untuk menyampaikan pendapat dan gagasangagasan pada forum tersendiri seperti rapat, kajian dan seminar.

Rapat harian adalah satu hal penting dalam organisasi guna menjaga roda organisasi dapat berjalan dengan lancar, pada rapat harian biasanya dilakukan minimal 10 orang dan di pimpin oleh pimpinan cabang, proses demikian dilakukan oleh PC IPNU guna membahas solusi terkait menangkal radikalisme pada pelajar. Tidak hanya lewat rapat saja akan tetapi juga lewat seminar yang dilakukan oleh pimpinan PC IPNU 
Ponorogo, seminar yang bertemakan penguatan akan kebangsaan dilakukan oleh PC IPNU Ponorogo ini menjelaskan betapa pentingnya bangsa Indonesia dan bahayanya faham radikalisme bagi bangsa

Menurut bendahara PC IPNU Ponorogo bahwa dalam menangkal faham radikalisme pimpinan PC IPNU Ponorogo mengadakan seminar yang bertemakan kebangsaan guna menanamkan kecintaan akan bangsa Indonesia dan memahamkan betapa bahayanya faham radikalisme terhadap bangsa khususnya bagi para pelajar kareana di dalam seminar yang bertemakan kebangsaan para pelajar atau peserta seminar akan diberi kesempatan untuk bertanya dan menggali lebih dalam lagi tentang faham radikalisme yang mereka belum ketahui. Seminar yang dilakukan oleh pimpinan PC IPNU Ponorogo akan memberikan pengetahuan bahayanya faham radikalisme, dan untuk lebih menekankan akan hasil dari seminar PC IPNU merangkum hasil seminar dan menyebarkannya kepada anggota lewat group WA yang ada untuk para peserta seminar. Hal ini dijelaskan oleh anggota PC IPNU Ponorogo bahwa apa yang dilakukan oleh pimpinan setelah seminar adalah menyebarkan kesimpulan dari seminar dan hal itu dilakukan oleh pimpinan guna mengingatkan kemabali kepada anggota agar tidak lupa dengan apa yang sudah di jelaskan pada seminar kan kebanyakan peserta seminar itu lupa dengan apa yang sudah di dapat pada seminar, selesai seminar ya sudah tidak imgat lagi apa yang disampaikan oleh pemateri seminar.

Peran pimpinan PC IPNU Ponorogo dalam memberikan informasi tentang faham radikalisme dari berbagai macam media memberikan dampak tersendiri kepada anggota, pengetahuan dan pemahaman akan faham radikalisme secara tidak langsung tertanam dengan sendirinya. Hal ini dikatakan oleh anggota PC IPNU Ponorogo dengan diberikannya informasi tentang faham radikalisme oleh pimpinan kepada para anggotanya lewat berbagai macam media yang ada membuat saya paham tentang bahayanya radikalisme dan itu membuat saya mengerti akan pentingnya kerukunan umat beragama apalagi di Indonesia ini bermacam-macam agama ada.

Anggota PC IPNU juga menegasakan dengan adanya informasi tentang faham radikalisme dari berbagai macam kegiatan membuat saya mengetahui bagaiamana faham radikalisme dari cara bekerjanya kepada para pelajar, dan itu membuat saya semakin cinta akan bangsa Indonesia ini yang bermacam suku agama dan budaya.

Pemberian pengetahuan akan bahayanya faham radikalisme tidak hanya lewat seminar atau kajian saja tapi juga memberikan pengetahuan keagamaan yang lebih mendalam kepada kader IPNU Ponorogo dengan cara pimpinan PC IPNU Ponorogo mengadakan silaturrahmi dengan para kyai NU dan juga senior-senior IPNU Ponorogo untuk menambah wawasan juga pengetahuan lebih mendalam tentang agama Islam yang rahmatan lil 'alamiin, hal ini seperti yang diungkapkan pengurus PC IPNU Ponorogo dalam menambah wawasan dan pengetahuan akan faham radikalisme kita selaku kader IPNU Ponorogo menimba ilmu kepada orang yang lebih tua seperrti para kyai NU dan juga para senior yang sudah berpengalaman di berbagai sector pemerintahan, seperti di dewan perwakilan rakyat, dinas-dinas dan juga kita menimba ilmu kepada stake holder lainnya seperti bupati, Polres dan Kodim.

Hasil dari proses komunikasi antara pimpinan PC IPNU Ponorogo dengan para stake holder tersebut dalam menangani faham radikalisme kemudian disampaikan kepada para pengurus dan anggota lewat berbagai macam media 
yang ada, seperti media online, buletin yang di tempel di papan informasi yang ada di secretariat PC IPNU Ponorogo dan diskusi secara langsung dengan para kader IPNU Ponorogo.

Secara teori pola komunikasi adalah sebagai berikut Pertama Pola komunikasi primer yaitu pola komunikasi primer merupakan suatu proses penyampaian pikiran oleh komunikator kepada komunikasi dengan menggunakan suatu lambang sebagai media maupun saluran, baik secara verbal maupun non verbal. ${ }^{39}$ Kedua Pola komunikasi sekunder yaitu proses komunikasi secara sekunder adalah proses penyampaian pesan oleh komunikator kepada komunikan dengan menggunakan alat atau sarana sebagai media kedua setelah memakai lambang sebagai media pertama. ${ }^{40}$

Komunikator menggunakan kedua media ini karna komunikan yang dijadikan sasaran komunikasinya jauh tempatnya atau banyak jumlahnya, atau keduaya jauh dan banyak. Komunikasi dalam proses secara sekunder ini senakin lama semakin efektif dan efisien karna didukung oleh teknologi komunikasi yang semakin canggih, yang ditupang pula oleh teknologi tenologi yang bukan tenologi komunikasi. ${ }^{41}$

Ketiga Pola komunikasi linear yaitu Istilah linear mengandung makna lurus. Jadi proses linear berarti perjalanan dari suatu titik ketitik yang lain secara lurus. Dalam konteks komunikasi, proses liniar adalah proses penyampaian pesan oleh komunikator kepada komunikan sebagai titik terminal. Komunikasi linear ini berlangsung dengan baik dalam situasi komunikasi tatap muka (face to face comunikation) maupun dalam situasi bermedia (mediated communication). ${ }^{42}$

\footnotetext{
39 Ibid., h. 31.

40 Deddy Mulyana, Ilmu Komunikasi...., h.

41 Ibid., h. 261.

${ }^{42}$ Ibid, h. 38.
} 260.
Keempat Pola komunikasi silkular yaiytu silkular sebagai terjemah dari perkataan "cilcular" secara harfiah berarti bulat, bundar dan keliling sebagai lawan dari kata linear tadi yang bermakna lurus. Dalam konteks komunikasi yang dimaksud dengan proses komunikasi silkular adalah terjadinya feedback atau umpan balik, yaitu terjadinya arus dari komunikan kepada komuniator. Oleh karna itu ada kalanya feedback tersebut mengalir dari komunikan kepada komunikator itu adalah "response" atau tanggapan komunikan terhadap pesan yang iya terima dari komunikator. ${ }^{11}$

Dari data dan teori diatas pola komunikasi yang digunakan oleh pimpinan PC IPNU Ponorogo adalah komunikasi primer ditunjukan dengan penggunaan Bahasa atau kata-kata yang digunakan oleh pimpinan cabang dalam berkomunikasi, komunikasi skunder ditunjukan dengan komunikasi yang dilakukan oleh pimpinan cabang menggunakan alat telekomunikasi yaitu handphone, sedangkan komunikasi silkuler yang dilakukan oleh pimpinan yaitu dengan mengadakan rapat, seminar, dan kajian-kajian yang dilakukan oleh pimpinan dan komunikasi linier ditunjukan oleh pimpinan PC IPNU Ponorogo dengan proses komunikasi dengan face to face kepada siapapun orangnya

Menurut Joseph A. devito membagi pola komunikasi menjadi empat, yakni komunikasi dengan diri sendiri, komunikasi antarpribadi, komunikasi kelompok dan komunikasi massa. ${ }^{43}$ Komunikasi dengan diri sendiri, Komunikasi antar pribadi, Komunikasi kelompok dan Komunikasi massa

Dari data dan teori diatas bahwa komunikasi yang dilakukan oleh pimpinan PC IPNU Ponorogo menurut Joseph A. Devito adalah komunikasi h. 28 .

${ }^{43}$ Nurudin, Sistem Komunikasi Indonesia....., 
dengan diri sendiri terlihat dari komunikasi pimpinan cabang dengan manghasilkan Tindakan nyata yang berwujud seminar dalam menangkal faham radikalisme. Komunikasi antar pribadi yaitu dilihatkan dengan cara pimpinan berkomunikasi dengan para senior dan stakeholder dalam menangkal faham radikalisme, komunikasi kelompok juga digunakan oleh pimpinan PC IPNU Ponorogo lewat forum seminar yang diadakan pimpinan PC IPNU dalam menangkal faham radikalisme dan untuk komunikasi massa pimpinan PC IPNU Ponorogo memperlihatkan dengan cara menyebarkan setiap informasi yang di dapat dari berbagai sumber lewat groupgroup WA yang terkait dengan PC IPNU Ponorogo.

Secara teori Menurut onong uchjana effendi proses komunikasi terbagi menjadi dua yaitu proses komunikasi primer dan proses komunikasi sekunder. Pertama Proses komunikasi primer. Proses komunikasi secara primer ialah proses penyampaian pikiran dan atau perasaan seseorang kepada orang lain dengan menggunakan lambang (simbol) sebagai media. Lambang sebagai media dalam proses komunikasi secara primer adalah bahasa, isyarat, gambar,warna dan lain sebagainya yang secara langsung mampu menterjemahkan pikiran atau perasaan komunikator kepada komunikan. ${ }^{44}$

Kedua Proses komunikasi sekunder. Proses komunikasi secara sekunder ialah proses penyampaian pesan oleh seseorang kepada orang lain dengan menggunakan alat atau sarana sebagai media kedua setelah memakai lambang sebagai media pertama. ${ }^{26}$

Dari data dan teori yang diungkapkan oleh onong uchjana effendi bahwa proses komunikasi yang dilakukan oleh pimpinan PC IPNU Ponorogo adalah

44 Onong Uchjana Effendy, Ilmu Komunikasi Teori dan Praktek...., h. 11. dengan cara komunikasi primer ditunjukan dengan menyampaikan apa yang menjadi kegelisahannya akan faham radikalisme terhadap pelajar lewat Bahasa, sedangkan komunikasi skunder yang dilakukan oleh pimpinan PC IPNU Ponorogo yaitu dengan cara lewat handphone sebagai sarana menyalurkan informasi-informasi terkait bahayanya faham radikalisme

Secara teori model komunikasi ada dua macam yaitu Model S-R dan model Aristoteles. Model Stimulus respons (S R) adalah model komunikasi paling dasar. Model ini di pengaruhi oleh disiplin psikologi, khususnya yang beraliran behavioristic. Model tersebut menggambarkan hubungan stimulusrespons. Model Aristoteles adalah model komunikasi paling klasik, yang sering juga disebut model retoris (rhetorical model). Ia berjasa dalam merumuskan model komunikasi verbal pertama. Komunikasi terjadi ketika seorang pembicara menyampaikan pembicaraannya kepada khalayak dalam upaya mengubah sikap mereka. Tepatnya ia mengemukakan tiga unsur dalam proses komunikasi, yaitu pembicara (speaker), pesan (message), dan pendengar (listener).

Dari data dan teori diatas bahwa model komunikasi yang dipakai oleh pimpinan PC IPNU Ponorogo adalah model komunikasi Aristoteles yaitu pimpinan PC IPNU Ponorogo mendapatkan informasi tentang faham radikalisme dan informasi yang di dapat diberikan kepada para kader IPNU Ponorogo.

\section{Kesimpulan}

Pimpinan PC IPNU Ponorgo dalam menangkal faham radikalisme yaitu dengan memberikan pengetahuan akan bahayanya faham radikalisme lewat media, diskusi dan menghargai tradisi.

Pola komunikasi yang dilakukan oleh pimpinan PC IPNU Ponorogo dalam 


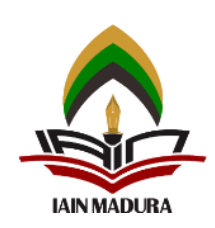

menangkal faham radikalisme adalah komunikasi primer, skunder, literal, dan sikular. Dan komunikasi yang dilakukan oleh pimpinan PC IPNU Ponorogo yaitu dengan komunikasi massa dan komunikasi kelompok.

\section{Daftar Pustaka}

Abdillah, Junaidi. 2014. Dekonstruksi Tafsir Ayat-Ayat 'Kekerasan' dalam AlQur'an. Jurnal Kalam: Studi Agama dan Pemikiran Islam 8: 283.

Ardianto. 2007. Komunikasi Massa Suatu Pengantar. Bandung: Simbiosa Rekatama Media.

Arsip Museum NU. Anggaran Dasar IPNU pada Muktamar ke III.

Cangara, Hafied. 2004. Pengantar Ilmu Komunikasi. Jakarta: Rajawali Pers.

Departemen Pendidikan dan Kebudayaan. 1996. Kamus Besar bahasa Indonesia. Jakarta: Balai Pustaka.

Effendy, Onong Uchjana. 1993. Dinamika Komunikasi. Bandung: PT Remaja Rosdakarya.

Komunikasi Teori dan Praktek.

Bandung: Remaja Rosdakarya.

Fadeli, Soelaiman. 2007. Antologi NU: Sejarah, Istilah, Amalia, Uswah. Surabaya: Khalista.

Fajar, Marhaeni. 2009. Ilmu Komunikasi \& Praktik. Yogyakarta: Graha ilmu.

Kartodirdjo, Sartono. 1985. Ratu Adil. Jakarta: Sinar Harapan.

Mansoer, Tolchah. 1955. Panduan Muktamar I IPNU. Malang: Panitia Muktamar I.

Marpaung, Rusdi dan Al Araf. 2003. Terorisme Definisi Aksi dan Regulasi. Jakarta: Imparsial.

Masduqi, Irwan. 2011. Berislam Secara Toleran. Bandung: Mizan.
Muhammad, Arni. 1992. Komunikasi Organisasi. Jakarta: Bumi Aksara

Mulyana, Deddy. 2010. Ilmu Komunikasi Suatu Pengantar. Bandung: PT. Remaja Rosdakarya.

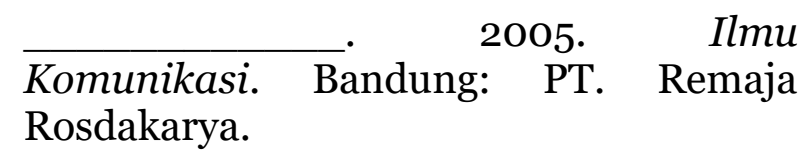

Munip, Abdul. 2012. Menangkal Radikalisme Agama di Sekolah. Jurnal Pendidikan Islam (JPI), Vol. 1: 162-165.

Nurudin. 2012. Sistem Komunikasi Indonesia. Jakarta: Rajawali Pers.

Parolin, Christina. 2010. Radical Spaces: Venues of Popular Politicts in London. Australia: ANU E Press.

Purnomo, Agus. 2009. Ideologi Kekerasan: Argumentasi Teologis-Sosial Radikalisme Islam. Yogyakarta: Pustaka Pelajar.

Qodir, Zuly. 2014. Radikalisme Agama di Indonesia. Yogyakarta: Pustaka Pelajar.

Riswandi. 2009. Ilmu Komunikasi. Yogyakarta: Graha Ilmu.

Rodin, Dede. 2016. Islam dan Radikalisme: Telaah atas Ayat-ayat 'Kekerasan' dalam al-Qur'an. Jurnal Addin, Vol. 10, No. 1: 35.

Rubaidi, A. 2010. Radikalisme Islam, Nahdlatul Ulama; Masa Depan Moderatisme Islam di Indonesia. Yogyakarta: Logung Pustaka.

Thontowi, Jawahir. 2004. Islam Neo imperalialisme dan Terorisme. Yogyakarta: UII Press.

Wirianto. 2004. Pengantar Ilmu Komunikasi. Jakarta: Gramedia.

Zada, Khamami. 2002. Islam Radikalisme. Jakarta: Teraju. 


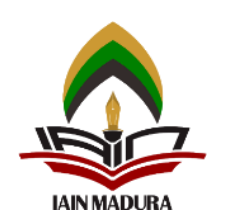

\section{Gambar}

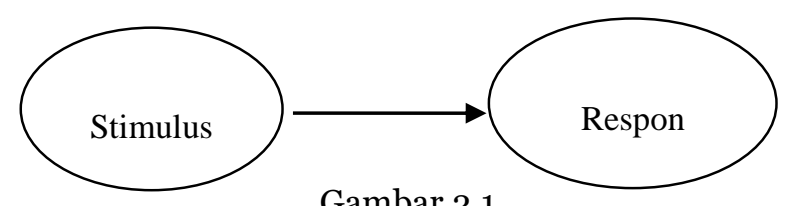

Model Stimulus Respons (S-R)

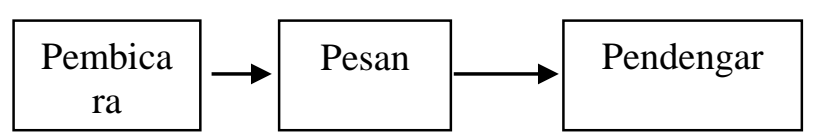

Gambar. 2.2

Model Komunikasi Aristoteles 